\title{
Factors Causing Sleep Disturbances among School Age Children with Sickle Cell Disease
}

\author{
MOUSA A.M. HASSAN, M.Sc.*; MIRRET M. DARWISH, D.N.Sc.*; HEWIDA A. HUSSIEN, D.N.Sc.* and \\ MARWA A. ABD EL-SAMED, M.D.** \\ The Departments of Pediatric Nursing, Faculty of Nursing* and Pediatric Medicine, Faculty of Medicine**, Cairo University
}

\begin{abstract}
Background: Sickle Cell Disease (SCD) is a group of inherited autosomal recessive hemolytic disorders. Sickle cell disease causes poor sleep quality that affect disease course. So it was important to assess causes of sleep disturbance among these children which in turn will improve children with SCD health outcomes and quality of life.
\end{abstract}

Aim of the Study: To assess factors causing sleep disturbances among school age children with SCD.

Patients and Methods: A purposive sample of 50 children who had SCD and attend the outpatient clinic of hematology for follow-up and eligible for inclusion criteria.

Tool of Data Collection: These were 4 tools which utilized which were personal characteristics and medical history sheet, knowledge assessment questionnaire, sleeping disturbance scale for children and structured questionnaire to assess factors causing sleep disturbance.

Results: The study results revealed that more than two thirds of children were between $6<9$ years with mean \pm standard deviation of age $8.5 \pm 1.71$ years and majority of them were male, majority of children suffer from mild sleep disturbances, minority suffer from severe sleep disturbances. The relationships between children's sleep disturbance level and environmental, psychological, medical and treatment factors were statistically significant. There was a positive correlation was detected between children's age from 9 to 12 years and their knowledge about SCD.

Duration of the Study: The study took about 7 months and half as it started from the beginning of October 2016 till half of May 2017.

Conclusion: The current study concluded that environmental, psychological, medical and treatment factors were factors causing sleep disturbances among school age children with SCD.

Recommendations: Assessment of sleep disturbances among children with SCD is important to determine its pattern,

Correspondence to: Dr. Mousa A.M. Hassan, The Department of Pediatric Nursing, Faculty of Nursing, Cairo University factors affect sleep disturbances and health education program should be designed and provided for children with SCD, their caregivers about SCD factors causing sleep disturbances and how to deal with them.

Key Words: Sickle cell disease - School age children - Sleep disturbances - Factors.

\section{Introduction}

SICKLE cell disease is one of a group of diseases collectively termed hemoglobinopathies in which normal adult hemoglobin ( $\mathrm{Hgb})(\mathrm{Hgb} \mathrm{A})$ is partially or completely replaced by abnormal sickle $\mathrm{Hgb}$ called hemoglobin $\mathrm{S}(\mathrm{HbS})$, in which a patient's red blood cells undergo a change of shape known as sickling, this shape change disrupts the normal flow of the red blood cells through the blood vessels of the body, ultimately preventing tissues from receiving adequate oxygen [1] .

Sickle cell disease is one of the most common genetic diseases in the world wide, it is estimated that SCD affects approximately 2,238 school age child in the United States, sickle cell disease is one of the most common genetic diseases in the world wide, over 300,000 newborn babies with SCD are born annually worldwide, the majority of these are in sub-Saharan Africa, where access to medical care and public health strategies to decrease mortality and morbidity are not uniformly available, this number is expected to increase to up to 400,000 patient with SCD by 2050 [2].

The clinical manifestations of SCD vary greatly in severity and frequency, the most acute symptoms of the disease; occur during periods of exacerbation called crisis. There are several types of episodic crisis, including vasoocclusive, acute splenic sequestration, aplastic, hyper hemolytic, cerebrovascular accident, chest syndrome and infection [3] . 
Guidelines for the treatment of SCD including a strong recommendation that hydroxyurea and long-term, periodic blood transfusions should be used more often to treat these children [4]. Other recommendations include the following: Use of daily oral prophylactic penicillin up to age 5 , annual transcranial doppler examinations between the ages of 2 and 16 years in patients with SCD, long-term blood transfusion therapy, rapid initiation of opioids for the treatment of severe pain associated with a vasoocclusive crisis, use of analgesics and physical therapy for the treatment of a vascular necrosis [5]

The general sleep patterns of school age children with SCD have not been well characterized, several studies have described the increased occurrence of specific sleep disorders and problems such as nocturnal hypoxemia and the disruption of sleep during pain episodes, but few have focused on more general sleep habits and behaviors such as total sleep time, bedtime behavior, and the number night waking as well as the incidence of sleep abnormalities such as parasomnias or excessive daytime sleepiness of children with SCD [6].

Sickle cell disease is a chronic disease that can be affected by environmental, health, and behavioral factors, understanding the impact of SCD on sleep is important to maximize the quality of life in these children. If the disease causes poor sleep quality, then children may be at risk for a host of developmental and psychosocial problems, beyond those caused by SCD, as a result of inadequate sleep [7].

Nursing interventions for sleep disturbances among school age children with SCD include: Assess the child's sleep patterns and usual bedtime rituals, provide measures to take before bedtime to assist with sleep such as quiet time to allow the mind to slow down and back massage, provide pain relief medications as prescribed shortly before bedtime and position patient comfortably for sleep, keep environment quiet such as avoid use of intercoms, lower volume on radio and television, encourage social activities and get outside for increased light exposure [8]. The nurse should emphasizes the importance of: Administering sufficient pain medication as prescribed to promote comfort, give large amount of oral or intravenous fluids according the prescription, to prevent fluid volume deficit, induce hemodilution and prevent further sickling and additional complications, maintain the child's normal body temperature, to prevent stress and maintain adequate metabolic state, reduce the child's energy expenditure to improve oxygenation, provide proper skin care to prevent skin breakdown, remove tight clothing to prevent inadequate circulation, teach school age child with SCD the relaxation techniques to decrease the child's stress level and suggest family screening and initiate genetic counseling to identify possible carries of the disease [9].

Sickle cell disease is one of the most common genetic diseases worldwide. Sickle cell disease affects approximately 90,000 Americans, primarily African American, followed by Hispanics, with a lower incidence in the other ethnic groups. The incidence of the disease varies in different geographic locations. Among African Americans, the incidence of SCD is about 9\%. In West Africa, the incidence is reported to be as high as $40 \%$ among native Africans [10].

Sickle cell disease causes poor sleep quality, children with SCD then may be at risk for developmental and psychological problems such as depression as the result of inadequate sleep in addition poor sleep may affect disease course. As Sickle cell disease is a chronic disease that can be affected by environmental, health, and behavioral factors, so understanding the impact of the disease on sleep is important to maximize the quality of life in these children [11]

\section{Research question:}

To fulfill the aim of the current study the following research question was formulated to be answered:

What are the factors causing sleep disturbances among school age children with sickle cell disease?

\section{Setting and Patients}

The current study was carried out at Hematology Outpatient Clinic which is allocated in the 2 nd floor at El-Monera Pediatric Hospital, Cairo University which is affiliated to Cairo University Hospitals. A purposive sample of 50 children who had SCD and attend the outpatient clinic of hematology for follow-up. The study took about 7 months and half as it started from the beginning of October 2016 till half of May 2017.

\section{Inclusion criteria of children:}

- School age children 6 to 12 years.

- Children of both genders.

- Children suffer from sleep disturbance such as insomnia, hypersomnia.

- Have SCD for at least 6 months ago.

- Free from other diseases that cause sleep distur- 
bance such as cardiovascular diseases and respiratory diseases.

\section{Study design and data collection:}

A descriptive exploratory research design was utilized for the purpose of the current study. Descriptive research design is used to describe phenomenon being studied, exploratory research design is defined as the initial research into hypothetical or theoretical, this is where a researcher has an idea or has observed something and seeks to understand more about it. It is an attempt to lay the ground work that will lead to future studies [12]

\section{Tools of the study:}

The required data were collected through the following tools:

Tool 1, 2 and 4 were developed by research investigator after reviewing recent and related literature as following:

1- Personal characteristics and medical history sheet: Included 2 parts as following:

- Part 1: Include personal data such as child's age, gender, birth order, residence and level of education.

- Part 2: Include medical history of the child such as number of previous hospitalization, consanguinity of fathers, family history of sickle cell disease, associations that help families who are not able to pay fees for treatment of SCD and children's treatment of sickle cell disease.

2- Knowledge assessment questionnaire: It used to assess school age child's knowledge about SCD. It included 9 questions such as definition, signs and symptoms, diagnosis, medical treatment, diet regimen, complication, curability of SCD and effect of SCD on school attendance. The questions were in form of multiple choice questions.

Scoring system of knowledge assessment questionnaire: Each correct answer scored by 1 and incorrect answer scored 0 score. The total numbers of questions are 9. The total scores are 9 and categorized as the following:

Children gained score from 0-4 - ${ }^{*}$ Indicated to have unsatisfactory knowledge about SCD.

Children gained score from 5-9 $-^{*}$ Indicated to have satisfactory knowledge about SCD.

3- The Sleeping Disturbance Scale for Children (SDSC): The scale was developed by [13] to assess sleeping pattern of school age children with SCD. This tool was adapted. It included 13 items divided into two parts as following:

- The first part: Indicates disorders of initiating and maintaining sleep which included 7 items such as how many hours of sleep does the child get on most nights and how long after going to bed does the child usually fall asleep.

- The second part: Indicates sleep wake transition which include 6 items such as the child startles or jerks parts of the body while falling asleep and the child grinds teeth during sleep.

Sleep disturbance scale for children consisted of 13 items rated on a 5 point likert type scale range from 1 to 5: As 1 indicates never has sleep disturbance, 2 indicates occasionally has sleep disturbance (once or twice per month or less), 3 indicates to some times have sleep disturbance (once or twice per week), 4 indicates to often have sleep disturbance ( 3 to 5 times per week), and 5 indicates to always (daily) has sleep disturbance.

\section{Scoring system of SDSC:}

The total numbers of items in the 2 parts of SDSC are 13 items. The total scores of part 1 are 35 and the total scores of part 2 are 30 . The total score of SDSC are 65; sleeping disturbance in SDSC categorized as following:

Children gain score 1-39 $-{ }^{\star}$ Indicates to have mild sleep disturbance.

Children gain score $40-52-{ }^{*}$ Indicates to have moderate sleep disturbance.

Children gain score 53-65 - ${ }^{\star}$ Indicates to have severe sleep disturbance.

4- A structured questionnaire to assess factors causing sleep disturbance: It was developed by the research investigator to assess factors causes sleep disturbances and it included questions related to environmental factors such as light, noise, psychological factors such as children bored from being ill, treatment factors such as medications used, and medical factors such as number of previous hospitalization.

\section{Tools validity and reliability:}

Validity: The tools for data collection were reviewed by five experts in the field of pediatric medicine nursing and pediatric hematology to test content validity of tools. Based on experts' comments recommendations and minor modifications had been made such as rephrasing and rearrangements of some sentences. 


\section{Reliability of the tools:}

The internal consistency was measured to identify the extent to which the items of the tools measure the same concept and correlate with each other. Internal consistency was measured to identify the extent to which the items of tools measure the same concept and correlated with each other using Cronbach's alpha test, is a function of the number of items in a test, the average covariance between items-pairs, and the variance of the total score. Cronbach's alpha coefficient was used to assess the internal consistency of the tools of the current study and its value for the knowledge assessment questionnaire was 0.81 which is accepted, its value for the sleeping disturbance scale for children was 0.90 which is excellent and its value for the structured questionnaire to assess factors causing sleep disturbance was 0.85 which is accepted.

\section{Pilot study:}

A pilot study was conducted on $10 \%$ of the total number of the sample to test feasibility and applicability of the study tools. There no modifications were done and pilot study sample included in the study.

\section{Statistical analysis:}

A Statistical Package for the Social Studies (SPSS) Version 21 was used for statistical analysis of data. Data were coded and summarized using descriptive statistics such as frequency, percentage distribution, mean and standard deviation for quantitative variables, Chi Square was used to compare qualitative variables and $(r)$ correlation coefficient was used to test the correlation between quantitative variables. The $p$-value $<0.05$ was considered a statistically significant.

\section{Results}

Table (1) shows that more than two third (68\%) of children in the study sample were between $6<9$ years with mean \pm SD of age $8.5 \pm 1.7$ years and $62 \%$ of them males, half $(50 \%)$ of them ranked as the first child, near half of the study sample (44\%) did not go to school, in relation to children residence, the same table reveals that $64 \%$ of children from rural areas.

In relation to sleep disturbance level it is evident from (Table 2) that near three quarter $(74 \%)$ of children have mild sleep disturbance, followed by $16 \%$ of children have moderate sleep disturbance, while only $10 \%$ of them have severe sleep disturbance.
Table (1): Frequency and percentage distribution of personal characteristics of children with SCD.

\begin{tabular}{lll}
\hline Items & No. $(\mathrm{n}=50)$ & $\%$ \\
\hline Age/years: & & \\
6<9 years & 34 & 68 \\
9-12 years & 16 & 32 \\
Mean \pm SD & $8.5 \pm 1.7$ & \\
Gender: & & \\
Male & 31 & 62 \\
Female & 19 & 38 \\
Birth order: & & \\
First child & 25 & 50 \\
Second child & 17 & 34 \\
Third child or more & 8 & 16 \\
Residence: & & \\
Rural & 32 & 64 \\
Urban & 18 & 36 \\
\hline
\end{tabular}

Table (2): Frequency and percentage distribution of level of sleep disturbance among children with SCD.

\begin{tabular}{lll}
\hline Items & No. $(\mathrm{n}=50)$ & $\%$ \\
\hline Sleep disturbance degree: & & \\
No sleep disturbance & 0 & 0 \\
Mild disturbance & 37 & 74 \\
Moderate disturbance & 8 & 16 \\
Severe disturbance & 5 & 10 \\
\hline
\end{tabular}

Table (3) clarifies that there were statistically significant relationships were observed between children's sleep disturbance level and children's age ( $\left.\chi{ }^{2}=6.407, p=.041\right)$, children's educational level $(\chi=21.979, p=.038)$, children's residence $\left(\chi^{2}=6.609, p=.037\right)$.

Table (3): Relationship between children's sleep disturbance level and their personal characteristics.

\begin{tabular}{|c|c|c|c|c|c|c|c|c|}
\hline \multirow{3}{*}{ Items } & \multicolumn{6}{|c|}{ Sleep disturbance level } & \multirow{3}{*}{$x^{2}$} & \multirow{3}{*}{$\begin{array}{c}p- \\
\text { value }\end{array}$} \\
\hline & \multicolumn{2}{|c|}{ Mild } & \multicolumn{4}{|c|}{ Moderate Severe } & & \\
\hline & No. & $\%$ & No. & $\%$ & No. & $\%$ & & \\
\hline \multicolumn{9}{|l|}{ Age: } \\
\hline $6<9$ years & 28 & 56 & 3 & 6 & 1 & 2 & 6.407 & $.041 *$ \\
\hline $9-12$ years & 9 & 18 & 5 & 10 & 4 & 8 & & \\
\hline \multicolumn{9}{|l|}{ Gender: } \\
\hline Male & 17 & 34 & 7 & 14 & 4 & 8 & 3.887 & .143 \\
\hline Female & 20 & 40 & 1 & 2 & 1 & 2 & & \\
\hline \multicolumn{9}{|l|}{ Birth order: } \\
\hline First & 15 & 30 & 6 & 12 & 4 & 8 & 6.012 & .198 \\
\hline Second & 14 & 28 & 2 & 4 & 1 & 2 & & \\
\hline Third or more & 8 & 16 & 0 & 0 & 0 & 0 & & \\
\hline \multicolumn{9}{|l|}{ Educational level: } \\
\hline Did not go to school & 19 & 38 & 2 & 4 & 1 & 2 & 21.979 & $.038 *$ \\
\hline Primary $1,2,3$ and 4 & 7 & 14 & 6 & 12 & 3 & 6 & & \\
\hline Can read and write & 7 & 14 & 0 & 0 & 0 & 0 & & \\
\hline Cannot read and write & 4 & 8 & 0 & 0 & 1 & 2 & & \\
\hline \multicolumn{9}{|l|}{ Residence: } \\
\hline Rural & 27 & 54 & 2 & 4 & 3 & 6 & 6.609 & $.037 *$ \\
\hline Urban & 10 & 20 & 6 & 12 & 2 & 4 & & \\
\hline
\end{tabular}

\footnotetext{
*: Statistically significant at $p<0.05$.
} 
It is clear from (Table 4) that there were statistically significant relationships were showed between children's sleep disturbance level and nearby noise sources, sources of noise in case of (yes), presence of insects in the house, and sleeping in dark room.

Table (4): Relationship between children's sleep disturbance level and environmental factors.

\begin{tabular}{|c|c|c|c|c|c|c|c|c|}
\hline \multirow{3}{*}{ Items } & \multicolumn{6}{|c|}{ Sleep disturbance level } & \multirow{3}{*}{$x^{2}$} & \multirow{3}{*}{$\begin{array}{c}p- \\
\text { value }\end{array}$} \\
\hline & \multicolumn{2}{|c|}{ Mild } & \multicolumn{2}{|c|}{ Moderate } & \multicolumn{2}{|c|}{ Severe } & & \\
\hline & No. & $\%$ & No. & $\%$ & No. & $\%$ & & \\
\hline \multicolumn{9}{|c|}{ Nearby noise source: } \\
\hline - Not present & 13 & 26 & 2 & 4 & 3 & 6 & 9.125 & $.00389 *$ \\
\hline - Present & 20 & 40 & 6 & 12 & 1 & 2 & & \\
\hline - Sometimes & 4 & 8 & 0 & 0 & 1 & 2 & & \\
\hline \multicolumn{9}{|c|}{$\begin{array}{l}\text { Sources of noise in } \\
\text { case of (yes): }\end{array}$} \\
\hline - Television & 10 & 20 & 2 & 4 & 1 & 2 & 9.159 & $.00279 *$ \\
\hline • Workshops & 8 & 16 & 1 & 2 & 0 & 0 & & \\
\hline - Metro/train & 4 & 8 & 2 & 4 & 1 & 2 & & \\
\hline - All of above & 2 & 4 & 1 & 2 & 0 & 0 & & \\
\hline \multicolumn{9}{|c|}{$\begin{array}{l}\text { Presence of insects in } \\
\text { the house: }\end{array}$} \\
\hline - Not present & 18 & 36 & 6 & 12 & 4 & 8 & 13.808 & $.008 *$ \\
\hline - Present & 19 & 38 & 2 & 4 & 0 & 0 & & \\
\hline - Sometimes & 0 & 0 & 0 & 0 & 1 & 2 & & \\
\hline \multirow{2}{*}{\multicolumn{9}{|c|}{$\begin{array}{l}\text { Availability of } \\
\text { comfortable sleeping } \\
\text { place: }\end{array}$}} \\
\hline & & & & & & & & \\
\hline - Not present & 14 & 28 & 2 & 4 & 0 & 0 & 3.113 & .211 \\
\hline - Present & 23 & 46 & 6 & 12 & 5 & 10 & & \\
\hline \multicolumn{9}{|c|}{$\begin{array}{l}\text { Watching scary } \\
\text { movies at bedtime: }\end{array}$} \\
\hline • No & 26 & 52 & 3 & 6 & 5 & 10 & 6.471 & .167 \\
\hline - Yes & 10 & 20 & 4 & 8 & 0 & 0 & & \\
\hline - Sometimes & 1 & 2 & 1 & 2 & 0 & 0 & & \\
\hline \multicolumn{9}{|l|}{$\begin{array}{l}\text { Listening to scary } \\
\text { tales at bedtime: }\end{array}$} \\
\hline - No & 24 & 48 & 2 & 4 & 4 & 8 & 7.512 & .111 \\
\hline - Yes & 11 & 22 & 5 & 10 & 0 & 0 & & \\
\hline - Sometimes & 2 & 4 & 1 & 2 & 1 & 2 & & \\
\hline \multicolumn{9}{|l|}{ Sleeping in dark } \\
\hline \multicolumn{9}{|l|}{ room: } \\
\hline - Dark room & 16 & 32 & 1 & 2 & 4 & 8 & 7.745 & $.0257^{*}$ \\
\hline $\begin{array}{l}\text { - Dark room } \\
\text { sometimes } \\
\text { light room }\end{array}$ & 4 & 8 & 2 & 4 & 0 & 0 & & \\
\hline - Light room & 16 & 32 & 5 & 10 & 1 & 2 & & \\
\hline
\end{tabular}

*: Statistically significant at $p<0.05$.

Table (5) explains that there were statistically significant relationships were detected between children's sleep disturbance level and children bored from treatment of SCD because of no hope in recovery, children have trust in doctor, children feel restricted by illness, children feel ashamed among peers because of SCD, children feeling of dependency because of SCD, children feeling of anger because of SCD and the cause of feeling anger is being absent from school.
Table (5): Relationship between children's sleep disturbance level and psychological factors.

\begin{tabular}{|c|c|c|c|c|c|c|c|c|}
\hline \multirow{3}{*}{ Items } & \multicolumn{6}{|c|}{ Sleep disturbance level } & \multirow{3}{*}{$x^{2}$} & \multirow{3}{*}{$\begin{array}{c}p- \\
\text { value }\end{array}$} \\
\hline & \multicolumn{2}{|c|}{ Mild } & \multicolumn{4}{|c|}{ Moderate Severe } & & \\
\hline & No. & $\%$ & No. & $\%$ & No & $\%$ & & \\
\hline \multicolumn{9}{|c|}{$\begin{array}{l}\text { Children bored from } \\
\text { treatment of } S C D \\
\text { because of no hope in } \\
\text { recovery: }\end{array}$} \\
\hline No & 15 & 30 & 2 & 4 & 1 & 2 & 10.307 & $.00420 *$ \\
\hline Yes & 22 & 44 & 6 & 12 & 4 & 8 & & \\
\hline \multicolumn{9}{|c|}{$\begin{array}{l}\text { Children have trust in } \\
\text { doctor: }\end{array}$} \\
\hline No & 27 & 54 & 4 & 8 & 2 & 4 & 8.221 & $.0200 *$ \\
\hline Yes & 10 & 20 & 4 & 8 & 3 & 6 & & \\
\hline Sometimes & 0 & 0 & 0 & 0 & 0 & 0 & & \\
\hline \multicolumn{9}{|c|}{$\begin{array}{l}\text { Children feel } \\
\text { restricted by SCD: }\end{array}$} \\
\hline $\begin{array}{l}\text { No } \\
\text { Yes }\end{array}$ & $\begin{array}{l}0 \\
37\end{array}$ & $\begin{array}{l}0 \\
74\end{array}$ & $\begin{array}{l}0 \\
6\end{array}$ & $\begin{array}{l}0 \\
12\end{array}$ & $\begin{array}{l}0 \\
4\end{array}$ & $\begin{array}{l}0 \\
8\end{array}$ & 9.220 & $.010^{*}$ \\
\hline Sometimes & 0 & 0 & 2 & 4 & 1 & 2 & & \\
\hline \multicolumn{9}{|c|}{$\begin{array}{l}\text { Children feel } \\
\text { ashamed among peers } \\
\text { because of SCD: }\end{array}$} \\
\hline No & 0 & 0 & 1 & 2 & 0 & 0 & 6.123 & $.0190 *$ \\
\hline Yes & 34 & 68 & 6 & 12 & 5 & 10 & & \\
\hline Sometimes & 3 & 6 & 1 & 2 & 0 & 0 & & \\
\hline \multicolumn{9}{|c|}{$\begin{array}{l}\text { Children feeling of } \\
\text { dependency because } \\
\text { of SCD: }\end{array}$} \\
\hline No & 0 & 0 & 1 & 2 & 0 & 0 & 5.676 & $.0225^{*}$ \\
\hline Yes & 36 & 72 & 7 & 14 & 5 & 10 & & \\
\hline Sometimes & 1 & 2 & 0 & 0 & 0 & 0 & & \\
\hline \multicolumn{9}{|c|}{$\begin{array}{l}\text { Children feeling of } \\
\text { anger because of } \\
\text { SCD: }\end{array}$} \\
\hline No & 0 & 0 & 1 & 2 & 0 & 0 & 6.186 & $.0186^{*}$ \\
\hline Yes & 34 & 68 & 6 & 12 & 4 & 8 & & \\
\hline Sometimes & 3 & 6 & 1 & 2 & 1 & 2 & & \\
\hline \multicolumn{9}{|c|}{$\begin{array}{l}\text { The cause of feeling } \\
\text { anger is being absent } \\
\text { from school: }\end{array}$} \\
\hline No & 22 & 44 & 1 & 2 & 4 & 8 & 7.735 & $.021 *$ \\
\hline Yes & 12 & 24 & 5 & 10 & 0 & 0 & & \\
\hline
\end{tabular}

*: Statistically significant at $p<0.05$.

Table (6) demonstrates that there was statistically significant relationships was observed between children's sleep disturbance level and medications of SCD that cause fatigue $\left(X^{2}=9 \cdot 156\right.$ $p=.0391)$.

Table (7) demonstrates that there were statistically significant relationships were detected between children's sleep disturbance level and chronic disease and its type (thalassemia) as a medical factor.

Table (8) shows that there was a positive correlation was detected between children's age from 9 to 12 years and their knowledge about SCD ( $r=$ $0.494, p=0.029)$. 
Table (6): Relationship between children's sleep disturbance level and treatment factors.

\begin{tabular}{|c|c|c|c|c|c|c|c|c|}
\hline \multirow{3}{*}{ Items } & \multicolumn{6}{|c|}{ Sleep disturbance level } & \multirow{3}{*}{$x^{2}$} & \multirow{3}{*}{$\begin{array}{c}p- \\
\text { value }\end{array}$} \\
\hline & \multicolumn{2}{|c|}{ Mild } & \multicolumn{2}{|c|}{ Moderate } & \multicolumn{2}{|c|}{ Severe } & & \\
\hline & No. & $\%$ & No. & $\%$ & No. & $\%$ & & \\
\hline \multicolumn{9}{|c|}{$\begin{array}{l}\text { Medications of SCD } \\
\text { cause fatigue/sleep } \\
\text { disturbance to } \\
\text { children: }\end{array}$} \\
\hline No & 1 & 2 & 1 & 2 & 0 & 0 & 9.156 & $.0391 *$ \\
\hline Yes & 36 & 72 & 7 & 14 & 5 & 10 & & \\
\hline \multicolumn{9}{|c|}{$\begin{array}{l}\text { Know the indications } \\
\text { of medications for } \\
\text { SCD: }\end{array}$} \\
\hline No & 25 & 50 & 6 & 12 & 3 & 6 & .330 & .848 \\
\hline Yes & 12 & 24 & 2 & 4 & 2 & 4 & & \\
\hline \multicolumn{9}{|c|}{$\begin{array}{l}\text { Remember to take } \\
\text { medication of SCD on } \\
\text { time: }\end{array}$} \\
\hline No & 11 & 22 & 2 & 4 & 1 & 2 & 4.408 & .354 \\
\hline Yes & 21 & 42 & 6 & 12 & 2 & 4 & & \\
\hline Sometimes & 5 & 10 & 0 & 0 & 2 & 4 & & \\
\hline \multicolumn{9}{|c|}{$\begin{array}{l}\text { Children with SCD } \\
\text { can get medications } \\
\text { easily: }\end{array}$} \\
\hline No & 28 & 56 & 8 & 16 & 3 & 6 & 4.865 & .301 \\
\hline Yes & 3 & 6 & 0 & 0 & 0 & 0 & & \\
\hline Sometimes & 6 & 12 & 0 & 0 & 2 & 4 & & \\
\hline
\end{tabular}

Table (7): Relationship between children's sleep disturbance level and medical factors.

\begin{tabular}{|c|c|c|c|c|c|}
\hline \multirow{3}{*}{ Items } & \multicolumn{3}{|c|}{ Sleep disturbance level } & \multirow{3}{*}{$x^{2}$} & \multirow{3}{*}{$\begin{array}{c}p- \\
\text { value }\end{array}$} \\
\hline & Mild & Moderate & Severe & & \\
\hline & No. $\%$ & No. & No. \% & & \\
\hline
\end{tabular}

\begin{tabular}{|c|c|c|c|c|c|c|c|c|}
\hline \multicolumn{9}{|c|}{$\begin{array}{l}\text { Have other chronic } \\
\text { diseases: }\end{array}$} \\
\hline No & 7 & 14 & 2 & 4 & 1 & 1 & 9.359 & $.0436 *$ \\
\hline Yes & 22 & 44 & 9 & 18 & 9 & 18 & & \\
\hline \multicolumn{9}{|c|}{$\begin{array}{l}\text { Type of chronic } \\
\text { disease in case of yes } \\
\text { is thalassemia: }\end{array}$} \\
\hline No & 0 & 0 & 0 & 0 & 0 & 0 & .714 & $.008^{*}$ \\
\hline Yes & 22 & 44 & 9 & 18 & 9 & 18 & & \\
\hline \multicolumn{9}{|c|}{$\begin{array}{l}\text { Duration of chronic } \\
\text { disease (thalassemia): }\end{array}$} \\
\hline Five years & 10 & 20 & 3 & 6 & 3 & 6 & 14.262 & 618 \\
\hline Six years & 5 & 10 & 3 & 6 & 2 & 4 & & \\
\hline Seven years & 3 & 6 & 2 & 4 & 1 & 2 & & \\
\hline Eight years & 2 & 4 & 1 & 2 & 1 & 2 & & \\
\hline Nine years & 1 & 2 & 0 & 0 & 1 & 2 & & \\
\hline Ten years & 1 & 2 & 1 & 2 & 0 & 0 & & \\
\hline
\end{tabular}

*: Statistically significant at $p<0.05$.

Table (8): Correlation between age of children and their knowledge level about SCD.

\begin{tabular}{lcc}
\hline \multirow{2}{*}{ Items } & \multicolumn{2}{c}{ Children's knowledge level about SCD } \\
\cline { 2 - 3 } & $r$ & $p$-value \\
\hline Age/years: & & \\
$6<9$ years & 0.159 & 0.433 \\
9-12 years & 0.494 & $0.029 *$ \\
\hline
\end{tabular}

*: Statistically significant at $p<0.05$.

\section{Discussion}

The results of the current study revealed that more than two thirds of children in the study sample were between $6<9$ years with mean \pm standard deviation of age was $8.5 \pm 1.7$ years. This study result is in accordance with the study of [14] who found that majority of children age was $8.223 \pm$ 1.681 years. Based on Erikson theory of development, this school age children are very active, develop sense of industry, enjoy team play, need to practice physical activity and lack of these help in development sense of inferiority and considered stressor in children with SCD which results in sleep disturbance.

The results of the current study founded that about two thirds of children were males and more than one third was females. This result is congruent with the study carried out by [15] under the title of: The relationship between occurrence of sleep problems and nocturnal enuresis in preschool age children with SCD, who showed that most of the children were males and the minority was females. The study result was corresponded to [16] who reported that SCD in males children were more than SCD in females children. The current study findings agree with study had done by [17] who found that about more than two thirds of children in their study were males. While the study result was contradicted with study carried out by [18] who studied the psychosocial adaptation of children and adolescents with sickle cell disease, who found that, more than half of children were females. From the research investigator point of view because incidence of SCD was more common in males than females children because SCD affects males more than females and in addition it reflects the Egyptian culture which families seek care for male children than females which enforce them to seek appropriate place of therapy for their male children.

The current study results explained that there was a positive relationship between sleep disturbance level and personal characteristics of children such as age, gender and socioeconomic status, this result is in accordance with study had done by [19] in the study titled effect of personal characteristics in sleep-disordered in children with SCD, who found that there was a relationship between sleep disturbance level and gender.

Regarding environmental factors the results of the current study found that there was a relationship between sleep disturbance level and environmental factors such as residence, number of sleeping rooms, the result of the current study is congruent 
with the study carried out by [20] who explained that sleep duration decreased in children with SCD because of increased incidence of daytime tiredness in children with SCD as a result of reduced sleep efficiency, which affected by environmental factors that disturb sleep such as co-sleeping, sharing rooms with family members, living in congested neighborhoods. The current study findings were in accordance with the studies of [21] who found that parents of children with SCD reported that significantly more behaviors associated with night waking and sleep-disordered and parasomnias related to noise from motor vehicles beside their houses. From the researcher point of view children with SCD have sleep disturbance as a result of environmental factors due to lack of availability of comfortable place, bed to sleep and crowdedness of bed rooms with different time schedule in addition to their chronicity of their disease and its complications schedule of treatment which can result in sleep disturbances.

As regards to psychological factors the results of the current study showed that there was a relationship between sleep disturbance level and psychological factors such as children feeling ashamed because of SCD, they bored from treatment of SCD due to no hope in recovery, this result is in accordance with [22] in their study under the title of "sleep disturbance, and pain in children with SCD", who revealed that most of the children with sickle cell disease had sleep disturbance.

In addition, the results of study are supported with the finding of [23] who demonstrated that children with SCD have sleep disturbances because of feeling restricted by SCD all the day. The result of the current study is in accordance with the findings of [24] in their study for children with SCD under the title of "quality of life of children patients with SCD", who stated that there was a high correlation between shorter sleep duration, insomnia and feeling of ashamed among their peers because of SCD.

But the results of the current study is contradicted with the finding of [25] who investigated psychological stress as a risk factor for sleep disturbances in children with SCD, who stated that stress negatively correlated sleep disturbances. From the researcher point of view this could be related to children with SCD have sleep disturbance because they suffer from stress due to children ashamed from their peers because they have chronic disease, prevent them from playing like other children, being dependent on others due to their illness, restrictions and all this results in thinking and stress and disturbances in their sleep.

In relation to treatment factors the results of the current study illustrated that there was a relationship between sleep disturbance level and treatment factors such as, analgesics for pain, these findings of the current study matched with the findings of [26] in the study of "Impact of depression and pain on sleep disturbance in children with SCD", who explained that more than two third of children with SCD report pain and pain becomes more severe in children as evidenced by a marked increase in the use of analgesics, the prevalence of pain continues to increase suggesting a substantial prevalence of chronic pain which causes disturbance in sleep.

The current study findings is also supported by the study of [27] under the title of "Effect of home management on sickle cell-related pain in children and adolescents", who stated that, analgesic medication was taken on most of children, who reported that the majority of children reported pain at nights which cause sleep disturbance to them.

The current study results demonstrated that near three quarter $(74 \%)$ of children have mild sleep disturbance, followed by $16 \%$ of children have moderate sleep disturbance, while only $10 \%$ of them have severe sleep disturbance which is in the same line with the finding of [28] in their study under the title of "Inadequate sleep and relationships to health and well-being of children with SCD", who found that the majority of children had mild sleep disturbances, minority of children had moderate sleep disturbances requiring changing pain medication one or two times per month to control pain and did not cause sleep disturbance.

The study results is supported with the findings of [29] in their study under the title of "Effect of short acting/long action opioids on sleep of children with SCD", who revealed that most of the children who take long acting opioids, taking analgesics for long time can cause disturb sleep of children. Also the results of the current study is in accordance with the finding of [30] who showed that changes in sleep architecture are due to medications taken for pain, disease processes, discomfort, lowered pain threshold, or a heightened arousal to bodily sensations keeping the individual from deeper stages of sleep.

The findings of the current study are in the same line with the finding of [31] who reported that the majority of children were receiving routine blood transfusion, reported moderate to severe 
sleep disturbance. This could be related to children with SCD, exposed to routine blood transfusion, frequent cannula insertion, analgesics from pain. All these are stressors of treatment which result in sleep disturbances.

Regarding medical factors the result of the current study illustrated that there was a relationship between sleep disturbance level and medical factors such as number of previous hospitalization, previous chronic illness, etc , these results in accordance with [32] who found that more than half of children have sleep disturbance because of frequent hospitalization, have other chronic disease, long duration of illness and lot of medications they take.

The current study results match with the study of [33] about the influence of medical treatment and stress on sleep in children with sickle cell disease, who found that most of the children have moderate sleep disturbance due to frequent laboratory investigations. This result is in accordance with findings of [34] under the title of exacerbation of sleep disorders in sickle cell disease by blood transfusion, who showed that more than two quarters of children were taking routine lab investigations, reported mild to moderate sleep disturbance. This could be related to children with SCD have sleep disturbance due to medical factors result from frequent hospitalization, have chronic diseases and frequent lab investigations, examination and all these are stressors which result in sleep disturbance.

The results of current study demonstrate that there was a positive correlation was detected between children's age about SCD and their level of knowledge about SCD. This result is in accordance with the findings of [35] study under the title of "Therapeutic challenges in childhood sickle cell disease", who revealed that the majority of children over 12 years old have satisfactory knowledge about SCD.

The current study findings is supported with the results of [36] in the study under the title of "Psychosocial adaptation of children with SCD", who found that there was a positive correlation between children's level of knowledge about SCD and their age. From the researcher point of view, when age of children increased there was an increase in their level of knowledge because SCD is a chronic disease and children knowledge increased by time through dealing with physician, nurses and other children with SCD who meet them in the outpatient hematology clinic weekly.

\section{Conclusion:}

In the light of current study findings, the current study concluded that environmental, psychological, medical and treatment factors were factors causes sleep disturbances among school age children with SCD.

\section{Recommendations:}

In light of findings of the current study, the following recommendations are suggested:

- Health education program should be designed and provided for children with SCD.

- Further studies with children with SCD are needed to assess the effect of controlling factors causing sleep disturbances among children with SCD on their sleeping patterns.

- Replication of the current study on large sample of children and at different hospitals settings to be able to generalize the results of the current study.

\section{References}

1- WONG D.L. and WALTON D.: Sleep disturbances in school-age children with chronic pain. Journal of Pediatric Psychology, 10: 420-30, 2015.

2- World Health Organization: Incidence of Sickle cell disease. Available at WWW.who.int/incidence of sickle cell disease/en, Accessed on 9/2016.

3- KWIATKOWSKI R. and MILLER R.L.: Essentials of Behavioral Research: Methods and Data Analysis. New York: McGraw-Hill, 7: 20-5, 2015.

4- ESTEY M.G. and AMADORI E.R.: Sleep-disordered breathing and nocturnal polyuria: Nocturia and enuresis. Sleep Medicine Reviews, 7: 22, 403-11, 2016.

5- YAWN E. and BUCHANAN J.B.: Habitual snoring, intermittent hypoxia and impaired behavior in primary school children. Pediatrics, 114: 8, 1041-8, 2017.

6- HOLLEN G.H.: Sleep disturbance and periodic limb movement disorder in children. Pediatric Clinics, 30: 6, 121-5, 2015.

7- WHALEY Y. and WONG D.L.: Wong's essentials of pediatric nursing. 10 th, ed. St. Louis: Mosby Co, 10: 111 $8,2015$.

8- SEEBER R.L. and SHANDER M.R.: Nocturnal enuresis in sickle cell disease. Expert Rev. Hematology, 7: 2, 24554, 2016.

9- FLOYD B.W.: Does sleep- disordered breathing contribute to the clinical severity of sickle cell anemia? Journal of Pediatric Hematology/Oncology, 18: 20, 135-9, 2016.

10- DRISCOLL M.: Prevalence and risk factors for sleepdisordered breathing in 8-to 11-year old children: Association with race and prematurity. Journal of Pediatrics, 142: 1, 383-9, 2017.

11-LEMANEK P.V. and LUPIA S.: The relationship between craniofacial morphology and obstructive sleep apnea in 
whites and in African Americans. American Journal of Respiratory and Critical Care Medicine, 163: 19, 947-50, 2015.

12- SHIELDS P. and RANGARJAN N.: A playbook for Research Methods: Integrating Conceptual Frameworks and Project Management. New Forums Press. Description categories, 71-8, 2013.

13- BRUNI O., OTTAVIANO S., GUIDETTI V., ROMOLI M., CORTESI F. and GIANNOTTI F.: The Sleep Disturbance Scale for Children (SDSC). Construction and validation of an instrument to evaluate sleep disturbances in childhood and adolescence. Journal of Sleep Research, 18 (5): 251-61, 1997.

14- ALI J.A., QADIR F.T., AHMAD G.S. and HUMAYUN F.D.: Parental attitude to children with sickle cell disease in selected health facilities in Irepodun Local Government, Kwara State, Nigeria. Studies on Ethno-Medicine, 5: 3340, 2014.

15-HODGES K., RICHARDS J. and KRANE J.: The influence of faith and religion and the role of religious and community leaders in prenatal decisions for sickle cell disorders and thalassemia major. Prenatal Diagnosis, 26: 801-9, 2013.

16- PALESH O.O., COLLIE A.I. and BATIUCHOK M.O.: Outcome of holistic care in Nigerian patients with sickle cell anemia. Clinical and Laboratory Hematology, 27: 195-9, 2015.

17- ASHLEY-KOCH Z.Y., SPLAINGARD G.J. and LASH A.F.: Sickle cell disease and pulmonary hypertension in Africa: A global perspective and review of epidemiology, pathophysiology, and management. American Journal of Hematology, 83: 63-70, 2016.

18- PANEPINTO S.J., TORRES F.D. and VARNI B.U.: Traditional herbal management of sickle cell anemia: Lessons from Nigeria. Anemia, 55: 87-92, 2016.

19- RAHIMY K., GANGBO F.E. and AHOUIGNAN O.O.: Psychosocial impact of sickle cell disorder: Perspectives from a Nigerian setting. Global Health, 21: 287-90, 2016.

20- SCHUTTE-RODIN R.A., BROCH D.C. and BUYSSE G.O.: Spectrum of musculo-skeletal disorders in sickle cell disease in Lagos, Nigeria. Journal of Orthopedic Surgery and Research, 5: 2-10, 2016.

21- MCCLISH C.T., ROBERTS Z.R. and DAHMAN G.R.: Improved survival of children and adolescents with sickle cell disease. Blood, 115: 3447-52, 2016

22- WISON G.R., GIL V. and BURCHINAL W.D.: Mortality from sickle cell disease in Africa. B.M.J., 330: 432-3, 2014.

23- AHMED A.J., HEWISON H.H. and GREEN E.D.: Susceptibility to invasive bacterial infections in children with sickle cell disease. Pediatric Blood \& Cancer, 55: 4016, 2015.

24- AFOLAYAN K. and JOLAYEMI F.K.: Screening newborns for sickle cell disease in Ghana. Pediatrics, 60: 200-10, 2016.

25- AMEH F.B., TARFA A.P. and EBESHI M.P.: Global epidemiology of sickle hemoglobin in neonates: A contemporary geostatistical model-based map and population estimates, 6: 150-5, 2017.

26- EL-SAADANY L., ABUO DONIA E. and SALEM M.A.: Neonatal screening and clinical care programs for sickle cell disorders in sub-Saharan Africa: Lessons from pilot studies. Public Health, 122: 933-41, 2013.

27- MINNITI M. and KRUMLAUF M.F.: Stable mixed hematopoietic chimerism after bone marrow transplantation for sickle cell anemia. Biology of Blood and Marrow Transplantation, 7: 665-73, 2015.

28- ECKES D.J. and OGUHEBE U.P.: The challenge of hemoglobinopathies in resource-poor countries. British Journal of Hematology, 7: 266-70, 2014.

29- WEISBERG S. and BALF-SORAN W.: Fatigue in adolescents and young adults with sickle cell disease: Biological and behavioral correlates and health-related quality of life. Journal of Pediatric Oncology Nursing, 31: 6-17, 2015 .

30- DORSEY S., et al.: Sleep problems in children with common medical disorders. Pediatric Clinics of North America, 51: 203-7, 2017.

31- GOZAL E.J. and MACK J.K.: Use of sleep hygiene in the treatment of insomnia. Sleep medicine reviews, 7: $215-25,2014$

32- LEVINE J.A. and KELLER K.F.: Sleep Disorders in Children. Handbook of Sleep Medicine, 9: 4, 165-8, 2017.

33- BROMBERG P. and SCHANBERG L.: Recent treatment guidelines for managing adult patients with sickle cell disease: Challenges in access to care, social issues, and adherence. Expert review of hematology, 9: 541-52, 2014.

34- FRIEDMAN L.J. and DAESCHNER M.: Sleep disruptions in parents of children and adolescents with chronic illnesses: Prevalence, causes, and consequences. Journal of Pediatric Psychology, 33: 279-91, 2015.

35- TSHILOLO C.H., AISSI A. and LUKUSA C.M.: Validation of the Insomnia Severity Index as an outcome measure for insomnia research. Sleep Medicine, 2: 297-307, 2016.

36- SPLAINGARD J.E. and BANDLA P.A.: Inflammation and behavioral symptoms after breast cancer treatment: Do fatigue, depression, and sleep disturbance share a common underlying mechanism? Journal of Clinical Oncology, 29: 3517-22, 2017. 


\section{العوامل التى تسبب إضطرابات النوم بين الآطفال فى سن المدرسة

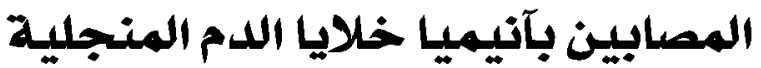

الهقدمة: مرض آنيميا الخلايا المنجلية هو مرض وداثى فى الدم ينتج عن نوع غير طبيعى من الهيموجلوبين يسمى الهيموجلوبين (إس)،

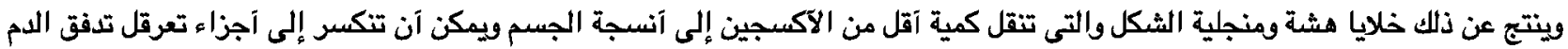

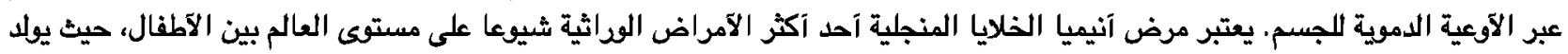

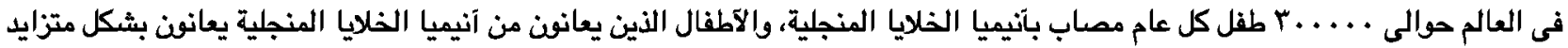

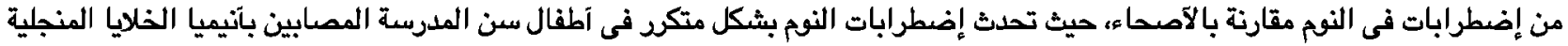

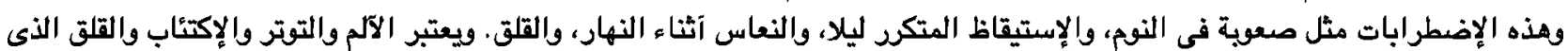
يعانى منه هؤلاء الآطفال آسباب مهمة فى الإصابة بإضطرابات الإنمات النوم لدى هؤلاء الآطفال.

هدف الرسيالة: إن الهدف من هذه الدراسة هو معرفة العوامل التى تسبب إضطرابات النوم بين الآطفال فى سن المدرسة المصابين بمرض آنيميا الخلايا المنجلية.

سؤال البحث: ما هى العوامل التى تسبب إضطرابات النوم بين الآطفال فى سن المدرسة المصابين بمرض آنيميا الخلايا المنجلية. مكان البحث: آجريت الدراسة الحالية فى عيادة آمراض الدم بمستشفى الآطفال الجامعى (المنيرة) التابعة لمستشفيات جامعة القاهرة. عينة البحث: إشتمل البحث على عينة لهدف الدراسة مكونة من عدد .0 طفل من الآطفال المصابين بآنيميا الخلايا المنجلية فى سن

تصميم الدراسة: تم إستخدام التصميم الإستكثافى الوصفى فى الدراسة الحالية لتحقيق الهدف.

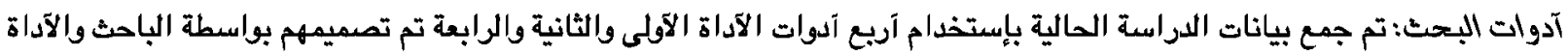

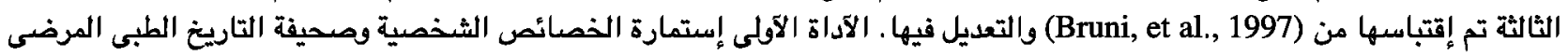

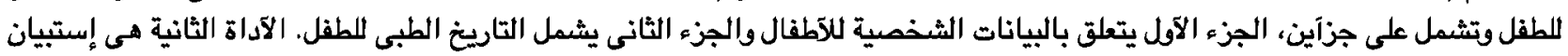

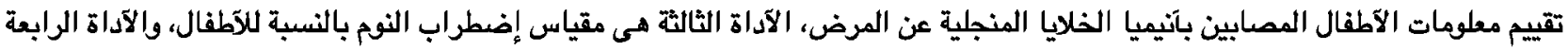
عبارة عن إستبيان لتقييم العوامل المسبية لإضطراب النوم عند الآطفال المصابين بآنيميا الذلايا المنجلية. نتانيج البحث: آهم النتائج المستخلصة من الدراسة الحالية:

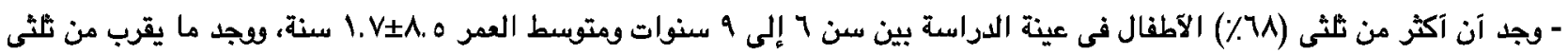

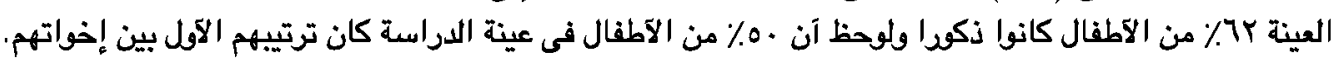

$$
\text { - وجد آن غالبية الآطفال (ع بـ) من الريف. }
$$

- وجد آن (عَ\%) من الآطفال ليس لديهم معلومات كافية عن مرض آنيميا الخلايا المنجلية.

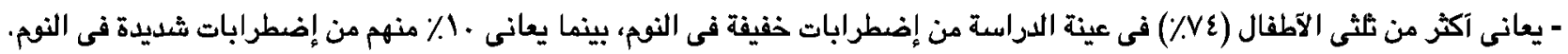
- توصلت الدراسة إلى وجود علاقة ذات دلالة إحصائية بين مستوى إضطراب النوم لدى الآطفال والعوامل التالية:

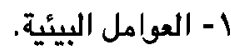

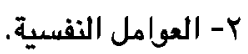

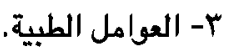

ع- العوامل العلاجية.

- أوضحت الدراسة وجود علاقة إيجابية بين عمر الآطفال من 9 إلى rإس سنة ومستوى المعلومات لديهم عن مرض آنيميا الخلايا المنجلية 
الخلاصة: فى ضوء نتائج الدراسة الحالية، خلصت الدراسة الحالية إلى آن العوامل البيئية والنفسية والطبية والعلاجية كانت من العوامل التى تسبب إضطرابات النوم بين الآطفال فى سن المدرسة الهصابين بآتيميا الخلايا المنجلية. التوصيات: على ضوء نتائج الدراسة الحالية تم إقتراح التوصيات التالية: - ضرورة تصميم وتتفيذ برنامج صحى للآطفال الذين يعانون من آنيميا الخلايا المنجلية والقائمين على رعايتهم عن العوامل التى تسبب إضطرابات التهات

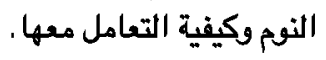
- هناك حاجة إلى مزيد من الدراسات مع الآطفال الذين يعانون من آنيميا الخلايا المنجلية لتقييم تآثير التحكم فى العوامل المسبية لإضطرابات النوم بين الآطفال الذين يعانون من آنيميا الخلايا المنجلية على طبيعة/نمط نومهم. - تكرار الدراسة الحالية على عينة آكبر وفى مستشفيات مختلفة وذلك لإمكانية تعميم نتائج الدراسة الحالية. 